Document downloaded from:

http://hdl.handle.net/10251/80331

This paper must be cited as:

Llopis Albert, C.; Palacios Marqués, D.; Merigó -Lindahl, JM. (2016). Decision making under uncertainty in environmental projects using mathematical simulation modeling.

Environmental Earth Sciences. 75(19):1-11. doi:10.1007/s12665-016-6135-y.

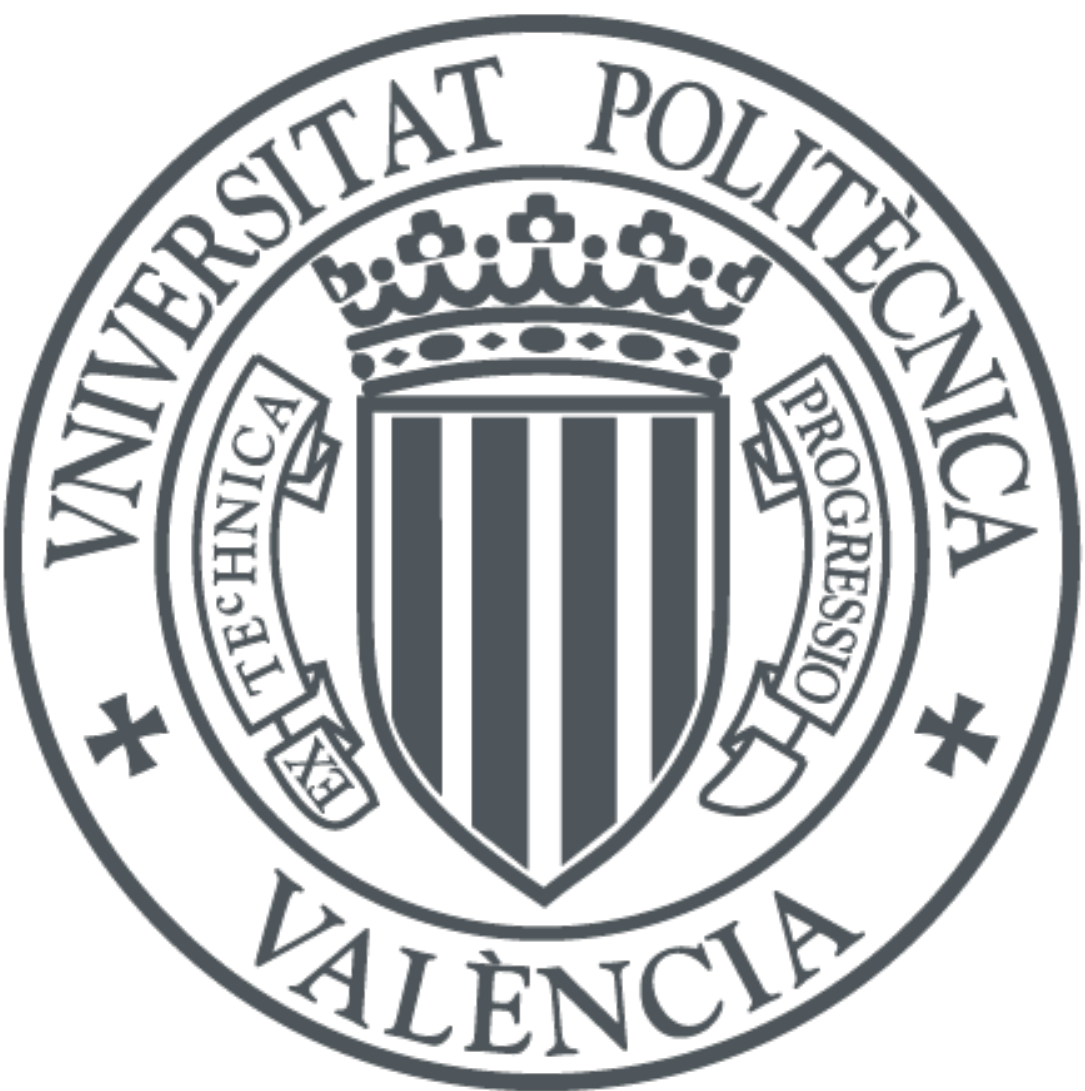

The final publication is available at

http://dx.doi.org/10.1007/s12665-016-6135-y

Copyright Springer Verlag (Germany)

Additional Information

The final publication is available at Springer via http://dx.doi.org/10.1007/s12665-016-6135-y 


\title{
Decision-making under uncertainty in environmental projects using mathematical simulation modeling
}

\author{
Carlos Llopis-Albert ${ }^{1}$, Daniel Palacios-Marqués ${ }^{2}$, José M. Merigó ${ }^{3}$ \\ 1 Universitat Politècnica de València, Camí de Vera s/n, 46022 Valencia, Spain, (Email: \\ cllopisa@gmail.com) \\ 2 Department of Business Organization, Universitat Politècnica de València, Camí de Vera s/n, \\ 46022 Valencia, Spain, (Email: dapamar@doe.upv.es) \\ 3 Department of Management Control and Information Systems, University of Chile, Av. Diagonal \\ Paraguay 257, 8330015 Santiago, Chile (Email: jmerigo@fen.uchile.cl)
}

\begin{abstract}
In decision-making processes, reliability and risk aversion play a decisive role. The aim of this study is to perform an uncertainty assessment of the effects of future scenarios of sustainable groundwater pumping strategies on the quantitative and chemical status of an aquifer. The good status of the aquifer is defined according to the terms established by the EU Water Framework Directive (WFD). A Decision Support Systems (DSS) is presented, which makes use of a stochastic inverse model (GC method) and geostatistical approaches to calibrate equally likely realizations of hydraulic conductivity $(K)$ fields for a particular case study. These K fields are conditional to available field data, including hard and soft information. Then, different future scenarios of groundwater pumping strategies are generated, based on historical information and WFD standards, and simulated for each one of the equally likely $K$ fields. The future scenarios lead to different environmental impacts and levels of socio-economic development of the region, and hence, to a different degree of acceptance among stakeholders. We have identified the different stakeholders implied in the decision-making process, the objectives pursued and the alternative actions that should be considered by stakeholders in a Public Participation Project (PPP). The MonteCarlo simulation provides a highly effective way for uncertainty assessment and allows presenting the results in in a simple and understandable way even for non-experts stakeholders. The methodology has been successfully applied to a real case study and lays the foundations to perform a PPP and stakeholders' involvement in a decision-making process as required by the WFD. The results of the methodology can help the decision-making process to come up with the best policies and regulations for a groundwater system under uncertainty in groundwater parameters and management strategies and involving stakeholders with conflicting interests.
\end{abstract}

Key words: Water resources management, uncertainty assessment, stakeholders, public participation projects, over-exploited aquifers, EU Water Framework Directive 


\section{Introduction}

Water resources management is facing great challenges, due to continual and growing pressure on water systems. Sustainable water resources management is complex because of the uncertainty in groundwater parameters, heterogeneous stakeholder interests, multiple objectives, land-use and climate changes, and future water availability and demands. Groundwater is an important and reliable resource for urban, industrial and irrigation for agricultural purposes, which can lead to a significant economic development of a region. Furthermore, it is a strategic and reliable resource in case of failure of other water sources, such as droughts, major breakdowns and pollution accidents. The decision-making process relates to situations such as pumping strategies to sustain irrigated crops and to supply groundwater to urban and industrial areas. In order to properly define such strategies it is necessary to understand the hydrogeological behavior of the groundwater system, to take into account the environmental standards, to consider heterogeneity and uncertainty, and the motivation and conflicting interests of stakeholders. For this purpose mathematical models have been exhaustively used in water resources management (e.g., Peña-Haro et al., 2010; 2011).

This work is applied to the Jumilla-Villena aquifer, which is located in Southeastern Spain. It calibrates equally likely realizations of hydraulic conductivity $(K)$ fields using a stochastic inverse model named GC method, which consider the physical processes taking place at the aquifer (Llopis-Albert 2008; Capilla and Llopis-Albert, 2009). A review about inverse methods in hydrogeology and their evolution and recent trends was presented by Zhou et al. (2014).

The calibrated $K$ fields will be conditional to hard data (i.e., measurements of $K$ and piezometric head data, h) and soft data (i.e., geophysical information and expert knowledge). Subsequently, we have generated and simulated future scenarios of sustainable groundwater pumping strategies for each one of the equally likely conditional $K$ fields. We have focused on $K$ in order to assess the uncertainty, since this is usually the parameter with the most significant spatial variation. Note that it can vary spatially by several orders of magnitude (e.g., Llopis-Albet and Capilla, 2009a). The simulated future pumping scenarios will lead to different environmental impacts and levels of socio-economic development of the region, and hence, to a different degree of acceptance among stakeholders. The MonteCarlo simulation allows performing an uncertainty assessment upon the future quantitative status of the aquifer, and therefore, to examine whether the system will meet the WFD standards (EC, 2000). In this sense, for case study analyzed we have 
identified the different stakeholders implied in the decision-making process, the objectives pursued and the alternative actions that should be considered by stakeholders in the public participation project (PPP). PPP are a step required by the WFD with the aim of enhancing water resource management and are exhaustively used (e.g., Wright and Fritsch, 2011). This work lays the foundations to perform a PPP and could be used as a decision support system to define the best management policies for the groundwater system. The results of the methodology can help the decision-making process to come up with the best policies and regulations for a groundwater system under uncertainty in groundwater parameter and management strategies (e.g., Molina et al., 2013). This is because the results of the methodology can be easily understandable by nontechnicians and non-experts stakeholders. Furthermore, the economical and environmental cost of groundwater can be compared with other sources of water such as desalinization plants, conjunctive use of groundwater and surface water, or transfer of water between river basins.

This work is in line with the EU Water Framework Directive (WFD), which requires that member states take the necessary measures to "protect, enhance and restore all bodies of groundwater", with the objective of reaching a good (quantitative and chemical) groundwater status by 2015 (EC, 2000). Therefore, any significant upward trend in the concentration of any pollutant should be identified and reversed as ruled by the Groundwater Directive (GWD) (EC, 2006).

Therefore, a numerical simulation model as that here presented -which explicitly take into account the biophysics of the aquifer and also integrate its socio-economic characterization by considering different scenarios- can help in both, the decision-making process and the uncertainty assessment.

\section{Application to the Jumilla-Villena aquifer (SE Spain)}

\subsection{Area of study and hydrogeological behavior}

An important part of the agricultural and economic development in the SE Spain is based on the aquifers over-exploitation. Large crop areas are irrigated exclusively with groundwater. In addition, the increase in the summer population because of tourism increases the demand for water, which is mainly satisfied by increasing the extractions from the aquifer. This intensive exploitation of the aquifers in the area has led to severe political conflicts between local towns, districts, regional governments and with the national government. Furthermore, the intensive exploitation of the groundwater bodies also produces important 
ecological impacts, ranging from the drying out of springs and wetlands, the disappearance and regime alteration of related rivers (Pulido-Velazquez et al., 2011), the pollution of water to water intrusion in coastal aquifers (Llopis-Albert and Pulido-Velazquez, 2014; 2015).

The Jumilla-Villena aquifer extends over parts of the provinces of Albacete, Alicante and Murcia (SE Spain), thus belonging to different regional governments. According to the Segura River Basin Authority the hidrologic unit code of this aquifer is 07.05 . SE Spain is characterized by a mild Mediterranean climate. The aquifer is constituted of Cretaceous carbonates and has a surface of over $338 \mathrm{~km}^{2}$, of which $108 \mathrm{~km}^{2}$ are outcrops. The average thickness of aquifer is $500 \mathrm{~m}$ and presents a syncline structural geology. The rock and water volumes (obtained for different effective porosities) were estimated through contour maps representing the same height above sea level. The economically exploitable reserves range from an elevation of 450 to 100 m.a.s.l. (i.e., using pumping wells between 100 and $400 \mathrm{~m}$ depth). These water reserves are about $1400 \mathrm{hm}^{3}$.

The aquifer has been officially declared as over-exploited in 1987, which means that well extractions are limited, irrigated surface cannot be increased and User's Communities must be set up as a control mechanism. Since extractions began the evolution of the piezometric level has been clearly negative. Therefore the aquifer is at extreme risk of not fulfilling the environmental goals set out in the EU WFD, as concerns their quantitative and qualitative conditions. The total annual abstractions in the aquifer present a mean value of $42.7 \mathrm{hm}^{3} /$ year for the time period from 1985 to 2004 , while the recharge is estimated in about $7.5 \mathrm{hm}^{3} /$ year (which is applied at permeable outcrops, i.e., $108 \mathrm{~km}^{2}$ with $65 \mathrm{~mm} /$ year). Hence the aquifer presents a water balance disequilibrium of about $35 \mathrm{hm}^{3} /$ year, despite the use of high-tech irrigation systems to ensure water efficiency. Moreover, we should add to the groundwater abstractions the intense period of drought experienced in recent years. During the last years the decline in piezometric levels have been maintained, or even accentuated, leading to about $5 \mathrm{~m}$ per year. The accumulated over-exploitation from the beginning of water abstractions is $1000 \mathrm{hm}^{3}$. As a consequence, the Segura River Basin Authority has been established the quantitative status of the groundwater body as one of the most important issues for the period from 2015 to 2021 (CHS, 2016). Then, the WFD objectives are not currently satisfied and there is a risk of not reaching good groundwater status over the different time horizons considered by the Directive, i.e., 2021 and 2027. 
The water demand and uses for the groundwater abstraction is presented in Table 1, while the annual water balance of the aquifer is shown in Table 2. There is no connection between surface water bodies and groundwater. Most of the water demand is for irrigation purposes, being the main crops in the aquifer woody, especially grapes and stone fruits. However, part of the water abstracted is used outside the limits of the aquifer. If that was restrained the water pressure in the aquifer could be reduced.

The water pressure has caused a deterioration in the natural quality of the water extracted, especially near the NE limit of the aquifer, where increased concentrations of $\mathrm{SO}_{4}^{-2}, \mathrm{Cl}^{-}, \mathrm{Na}^{-}$, and $\mathrm{Ca}^{2+}$ have been recorded. Moreover, the increase in nitrate concentrations, as a result of the fertilizer application in the irrigated crops, is becoming an important issue in the region. Additionally, before the start of the exploitations there were two springs (La Ñorica and El Chopo) that became dry because of the abstractions. They had an average annual discharge of 0.6 and $6 \mathrm{hm}^{3}$, respectively.

Other root of the problem lies in the conflicting stakeholder interests, which are often an important impediment to the realization and success of any regulations and policies. This situation gets worse when managing water resources that are manifestly scarce. With respect to the institutional dimensions of the problem the aquifer has User's Communities, but their actions are constrained by the limited means available to them. As a last resort the water management of the aquifer depends on the River Basin Agencies. In this sense, the aquifer is shared between the Segura and Júcar River Basin Authorities, thus leading to water transfers between them (CHS, 2016; CHJ, 2016).

\subsection{Modeling framework}

The future scenarios with regard to pumping strategies are intended to analyze if the system will achieve the good quantitative groundwater status in the context of the WFD. These scenarios are simulated by making use of a calibrated groundwater flow model. The calibration of the hydrogeological parameters of the flow equation has been carried out by means of the GC method, which constitutes a stochastic inverse modelling technique for the simulation of conductivity $(K)$ fields. There is an exhaustive literature regarding the GC method, which was initially presented by Llopis-Albert (2008) and Capilla and Llopis-Albert (2009). A verification on a 2D synthetic aquifer was shown by Llopis-Albert and Capilla (2009). It was also applied to the Macrodispersion Experiment (MADE-2) site, on a highly heterogeneous aquifer at Columbus 
Air Force Base in Mississippi (USA) (Llopis-Albert and Capilla, 2009a), and on complex real-world case study in a fractured rock site (Llopis-Albert and Capilla, 2010). Moreover, it was extended to deal with independent stochastic structures belonging to independent $K$ statistical populations (SP) of fracture families and the rock matrix, each one with its own statistical properties (Llopis-Albert and Capilla, 2010a). In addition, the stochastic inverse method was coupled with a management model for dealing with nonpoint agriculture pollution and with a sharp interface model for dealing with seawater intrusion in coastal aquifers under groundwater parameter uncertainty (Llopis-Albert et al., 2014; 2016). The structure adaptation of the $K$ fields while integrating the conditional information was analyzed in Llopis-Albert et al. (2015). Therefore the sake of conciseness, the reader is referred to those papers for all details of the methodology, and only a brief description of the capabilities of the GC method is subsequently presented. It uses a modified version of the gradual deformation technique ( $\mathrm{Hu}, 2000)$, which consists of an iterative optimization process for constraining stochastic simulations to flow and mass transport data. This is performed by means of successive non-linear combinations of seed $K$ realizations (which honour $K$ measurements and soft data obtained from expert judgment and/or geophysical surveys) with the conditional $K$ field resulting from a previous iteration. The procedure requires combining at least three conditional realizations at a time to ensure the preservation of mean, variance, variogram and data conditioning in the linearly combined field, for which linear combination coefficients must fulfil several constraints. Every combination of fields requires minimizing a penalty function that penalizes the difference between computed and measured conditioning data. Therefore, the calibration process has been carried out by considering the physical processes taking place in the aquifer.

As a result of the calibration process, an ensemble of a 100 calibrated $K$ fields is obtained. Then the future pumping scenarios are simulated for each one of these $K$ fields using the code MODFLOW (McDonald and Harbaugh 1988; Harbaugh et al. 2000), which solves the groundwater flow equation in a porous medium in three dimensions using an approximation by finite differences and a constant density.

\subsection{Model domain, spatial and temporal discretization, and initial and boundary conditions}

The model domain has 79 columns, 26 rows, and 1 layer, with 2054 square cells of size $500 \mathrm{~m}$, thus covering a flow domain of $13 \times 39.5 \mathrm{~km}$. It is considered as an unconfined aquifer. The active model domain was defined by making model limits coincide with the physical limits of the system, so that no flow boundary 
conditions were used. Within the aquifer limits there are only 1352 cells, which are considered active cells in the finite difference model. The fractures are small relative to cell size, so the use of the finite difference scheme is appropriate (Jagelke and Barthel 2005). The temporal discretization was defined for a period of 19 years (1985-2004), with stress periods taken on a monthly time step. The initial piezometric head field was obtained by interpolating the 52 observations available at 1984 .

\subsection{Recharge and groundwater pumping}

There are 73 abstraction wells and the 59 head observation boreholes spatially distributed in the aquifer. The total annual abstractions in the aquifer for the whole simulated period present a mean value of 42.7 $\mathrm{hm}^{3} /$ year. A uniformly distributed recharge of $7.5 \mathrm{hm}^{3} /$ year was applied at permeable outcrops (i.e., 108 $\mathrm{km}^{2}$ with $65 \mathrm{~mm} /$ year). This leads to a water balance disequilibrium of about $35 \mathrm{hm}^{3} /$ year. Due to the high agrarian profitability, the distribution system supplies water to the irrigated crops from the abstraction wells to tens of kilometers.

\subsection{Model calibration and validation. Hydrogeological parameters}

The calibration of the flow model using the GC method was performed using historical data, such as hydraulic conductivities, piezometric heads, pumping rates and recharge; pumping tests and expert judgment (CHS 2016). The piezometric head information was obtained from 59 boreholes spatially distributed and covering the whole time period considered. The uncertainty in the seed $K$ realizations is tackled by means of sequential indicator simulation using the computer code ISIM3D (Gómez-Hernández and Srivastava, 1990). The stochastic structure of $K$ has been defined using the local conditional cumulative density function (ccdf) defined using $K$ measurements and the corresponding indicator variograms, as well as other types of information from expert judgement or from geophysical surveys (Capilla and LlopisAlbert, 2009). Consequently, all $K$ fields are equally likely realizations and plausible representations of reality, since they display the same degree of spatial variability. The calibration process consisted of adjusting the data entered into the model so that the groundwater levels simulated were close to the measurements, while honoring the $K$ measurements. 
The final calibrated parameters for the ensemble $K$ fields that hydraulically characterize the aquifer ranges from 0.1 to $15 \mathrm{~m} / \mathrm{d}$ for the hydraulic conductivity $(K)$; from 0.002 to 0.04 for the specific yield $\left(S_{y}\right)$; and from $10^{-5}$ to $5 \cdot 10^{-4}(1 / \mathrm{m})$ for the specific storage $\left(S_{s}\right)$. A good agreement between simulated and observed values was obtained after the calibration process for all the boreholes and the 100 calibrated $K$ fields, as shown in Fig. 1 and Fig. 2. This is because multiple sets of parameters or model structures can be an equally good or bad approach to represent the water system, which is named equifinality in the literature (e.g., Arhonditsis et al., 2008).

In addition, the calibrated $K$ fields have been validated by means of the reproduction of the natural regime of the aquifer; the consistency of the parameters and results with the conceptual model and hydrogeology expected in the aquifer; and the expert judgment. Finally, the calibrated fields also allow understanding the long transient stages involved in the development of the aquifer (it is a well-known fact the long-term transient effects and the delayed response of the aquifer due to the external stresses, such as well abstractions, recharge, etc.). Salinity and water-quality changes still evolve at a slower pace than water level changes. This is because they depend on physical groundwater movement, both in the unsaturated and saturated zone, while head changes only imply small water displacements (Custodio, 2002).

\subsection{Scenarios}

Four future scenarios with regard to pumping strategies were analyzed, which entail different environmental impacts and levels of socio-economic development of the region. Therefore, these scenarios lead to a different degree of acceptance among stakeholders. The scenarios or different alternatives of water abstractions are based on different reports published by the Segura River Basin Authority, such as the Scheme of Important Issues and the Hydrologic Plan, which are mandatory as established by the EU WFD (CHS, 2016). The first alternative is the business as usual situation, i.e., to continue with the actual rate of exploitations. The second option entails the use of external water resources to reduce the water pressure, such as water transfers from other river basins. The third alternative consist of reducing the irrigated areas by gradual acquisition of water rights, which will be selectively applied on crop areas with lower productivity.

Scenario 1 (S1): cessation of abstractions in the year 2004 and recovery of the aquifer until the year 2025. 
Scenario 2 (S2): abstractions of the year 2004 are used until the year 2007. After this year there is a cessation of abstractions and the recovery of the aquifer takes place until the year 2025 .

Scenario 3 (S3): abstractions of the year 2004 are used until the year 2007. Then the abstractions of the Register of Water (RW) of the Segura River Basin Authority are used until 2015. The RW entails 65.35 $\mathrm{hm}^{3} /$ year. Finally, a half of the RW abstractions are simulated up to the year 2025 .

Scenario 4 (S4): abstractions of the year 2004 are used until the year 2007. A half of the RW until 2015 and a quarter of RW up to the year 2025.

Using one of the calibrated $K$ fields these four future scenarios with regard to pumping strategies were simulated (Fig. 1). The model allows obtaining the groundwater level and drawdown in the aquifer, thus providing a tool to analyze if the system will achieve the good quantitative and chemical groundwater status as ruled by the WFD.

\section{Results of the future pumping scenarios.}

Fig. 1 illustrates the head-time curves of the observations and simulated values (for one of the calibrated K fields) for all scenarios at a specific well. These values are shown for the calibration time period and for the future scenarios of pumping strategies. This figure shows the good agreement between the calculated and observed head values for the calibration time period. It also depicts that scenarios S1 and S2 entail a slight recovery of the water levels. However, scenarios S3 and S4, with more intensive exploitations, show how water levels continue decreasing (with a mean drawdown for all wells of more than a hundred meters since the natural regime of the aquifer). These drops present different slopes as a consequence of the intensity of the future pumping strategies. Similar declines in water levels are observed for the rest of the observation boreholes, which are not shown for the sake of conciseness. For all scenarios because of the cumulative over-exploitation higher than $1000 \mathrm{hm}^{3}$, with an estimated recharge of only $7 \mathrm{hm}^{3} /$ year, the environmental objectives regarding the recovery of the natural regime of the aquifer are dismissed. Concretely, with the S1 conditions the water levels in the aquifer rise but without reaching the initial levels of 1985 . However, some piezometers present declines due to redistribution of water and recovery of the cones of depression. A similar behavior is obtained for S2, although because of having three more years of extractions the groundwater levels increase is lower. For S2 scenario none of the cells containing pumping wells become dry although the groundwater levels continue dropping from 2004 to 2007. From the year 2008 onwards the groundwater levels increase although without reaching the levels of the year 1985 . S3 represents the 
most demanding scenario with regard to exploitations. For this scenario the groundwater levels decline continues until 2025 at a similar rate to that existing for the calibration period. Eight cells containing eleven pumping wells become dry. Five pumping wells dried up, in the year 2010, which entails a reduction of the RW from 65.35 to $59.98 \mathrm{hm}^{3} /$ year. In the year 2015 three more pumping wells dried up, thus lowering the abstractions up to $49.89 \mathrm{hm}^{3} /$ year. This only represents a $76.3 \%$ of the RW. In the year 2025 no more pumping wells dried up, being the exploitation half of the RW. Therefore, it decreases to $24.94 \mathrm{hm}^{3} / \mathrm{year}$ Simulation results show that groundwater levels decline until 2025 at a similar rate to the calibration period. The average decrease of the piezometers is about $100 \mathrm{~m}$. Nevertheless, some piezometers present a slight increase in the levels because of redistribution of water and recovery of the cones of depression. In the scenario S4 groundwater levels drops at a lower rate to that exhibit in the scenario S3, although the latter presents a steeper slope. Note that the exploitation for S4 is only $25 \%$ of the RW since 2015 . In addition, none of the cells containing pumping wells dried up.

The calibrated model also allows analyzing the evolution of water balance between the Segura and Júcar River Basin Authority. The net transfer water between the watersheds show a mean value of $7.5 \mathrm{hm}^{3} / \mathrm{year}^{-}$ for the calibration time period. This has highly sensitive implications regarding water management between the different stakeholders involved. Therefore, the present work can help to define the best management practices in the aquifer.

A zonification study of the aquifer has also carried out. The aquifer has been divided in the three zones (Eastern, Western and Central). The central zone of the aquifer discharges to the other two zones with a transfer (depending on the definition of the zones and the future scenarios) of about $5 \mathrm{hm}^{3} /$ year.

An additional result was to perform a sensitivity analyses with regard to the aquifer recharge. When using a half of the estimated recharge the model is insensitive because the recharge is much lower than the exploitations. Contrary the model is sensitive when the recharge is duplicated. Note that in this case the recharge has a considerable value regarding exploitations. Then a recharge considerably higher than the estimated value of $7.5 \mathrm{hm}^{3} /$ year is dismissed.

There are no signs of ground subsidence or general deterioration of water quality. The most sensitive areas are the eastern boundary of the aquifer and the northwestern area nearby the "Duero" well, but this is a local problem related to the well location relative to the saline aquifer boundary. 
The aquifer is not connected to surface water bodies. The main environmental impact occurred in the early twentieth century when the springs were regulated as a result of the initial pumping of the aquifer. In the current situation, the aquifer does not hold any Groundwater dependent ecosystems (GDE) such as rivers, wetlands, springs, streams, lagoons, etc. Note that the degree and nature of dependency will influence the extent to which ecosystems are affected by changes to the groundwater system, both in quality and quantity.

The simulation results show that it is possible to maintain almost the current abstractions until the year 2025 , although there will be a gradual increase of the energy cost of pumping and arise the necessity of making deeper wells or even change the location of some of them in the worse situation. This could be carried out at much lower costs if compared to other water resources such as imported, desalinated, or reused (CHS, 2016). Moreover, the current cost of desalination $\left(€ / \mathrm{m}^{3}\right)$ may increase in the future because higher energy costs are expected .Therefore, it is not feasible to replace groundwater uses except in certain cases. However, the water abstracted from some wells is brackish and needs treatment by reverse osmosis.

Of course, the abstractions will be continued in the context of the inherent shortage of water and an expected increase in future demands of water in the aquifer. Therefore, with the existing extractions, in order to satisfy water demands of the region, the recovery of the aquifer cannot be achieved. This is true even with the pumping scenario S1, which entail the cessation of abstractions in the year 2004 and recovery of the aquifer until the year 2025. Fig. 1 shows how the groundwater levels are recovering after the cessation of abstractions, but the complete recovery to the levels prior major abstractions would require more long-term. The recovery for scenario S2 would require an even more long-term, while for scenarios S3 and S4 the recovery is infeasible. Besides, the current nitrate concentrations in the aquifer are below standards (50 $\mathrm{mg} / \mathrm{l})$ (CHS, 2016). Despite these facts, the water demand has clear benefits regarding the economy of the region, including agricultural, industrial and urban activities. In addition, this entails that quality problems such as the water salinity or the purpose of keeping the nitrate concentrations within the target levels, as defined by the WFD, might worsen.

Fig. 2 shows head time series for the ensemble calibrated $K$ fields (100 fields) and Scenario S3 (the most water demanding scenario) at a specific spatial location. On the one hand, all calibrated $K$ fields show a good agreement between the calculated and observed head values and how water levels continue decreasing. Again, a good agreement has also been achieved for the rest of the observation boreholes. On the other hand, the uncertainty can be assessed by means of the different $K$ fields, which present a significant variance with a difference in piezometric heads of more than $30 \mathrm{~m}$ between them for a specific time. This 
shows the importance of using a tool as that here presented to perform an environmental project with public participation, which involves stakeholders with conflicting interests.

\section{Public participation project and stakeholders' involvement. Application to a case study.}

Public participation and stakeholders' involvement in water resource management has gained increasing significance over the last decades. In this sense, the WFD requires the public and stakeholder participation with the aim of enhancing water resource management. Three levels of participation with different degree of influence are identified to involve individuals and groups in a democratic way: information supply, consultation and active involvement. The decision making process based on public participation and stakeholders' involvement should take the following steps (Reichert et al., 2005): definition of the decision problem, identification of objectives and attributes, identification and pre-selection of alternatives, prediction of outcomes, quantification of preferences of stakeholders and decision makers for outcomes, ranking of alternatives, assessment of results.

A PPP have already been performed by the Segura River Basin Authority, as established by the WFD. For each hydrological planning cycle (2009-2015 and 2015-2021) a PPP were performed. It ranges from the Schema of Important Issues, the Strategic Environmental Report, the Flood Risk Management Plan, to the Hydrologic Plan for the river basin (CHS, 2016). As a transparency and confidence-building measure all information and reports are posted in the webpage of the Segura Water Agency (CHS, 2016).

The stakeholders with different level of participation have been identified, which include public administration and institutions (e.g., national government, Segura and Júcar water agencies, reginal governments, municipalities...), environmental organizations (e.g., NGO's), water users' communities, private firms (e.g., water or hydroelectric companies, tourism organizations), scientific agencies (e.g., universities and the Geological Survey of Spain), experts, mass-media, labor unions and citizens. The criteria used to select the stakeholders is based on considering all the groups who in some way will be affected by the implementation of measures. This may include those who have interests, claims or rights (ethical or legal) to the benefits of the measures undertaken, are likely to bear its costs or adverse impacts whatever its overall worth. Then, we have not only included those groups whose interests, resources, and position of power/authority imply that they are likely to affect substantially the way in which the measures will be implemented. 
With the aim of fostering greater contribution of stakeholders the PPP includes public information campaigns, divulgative activities, establishment of a stakeholder organization registry, meetings, sector and territorial round tables, debate forums, workshops, surveys, etc.

Stakeholders deal with a wide range of issues such as evolution of natural and available water resources and their quality; degree of compliance with environmental objectives and ecological flows; state bodies of surface and ground water and their evolution in achieving the proposed environmental objectives; implementation of programs of measures and effects on water bodies; socio-economic analysis and cost recovery; designation of protected areas, artificial and heavily modified water bodies; river basin operating system; transfer of water resources; use of desalination and sewage water plants, etc. Other issues that should be taken into account are current and future water demand, the consequences of the new EU Common Agricultural Policy 2014-2020 (CAP), evolution of electricity and energy sectors, land use-land cover changes, forecasts on climate change, paying particular attention to phenomena such as erosion and desertification.

There was an official calendar with the main phases of PPP and a period for observations and allegations was arranged. With regard to the initial documents, prepared by the Segura Water Agency, more than a hundred contributions have been made by the different stakeholders. All contributions of stakeholders were taken into account and formally responded by the Water Agency. Eventually, some of them were incorporated to the final documents and proposals. The modifications and additions to the initial documents were focused on various aspects, among which were environmental and ecological flows, water resources and demands as well as considerations about the articulation of the PPP.

Satisfaction surveys and rating performance levels of the PPP were performed among stakeholders. The surveys assessed questions such as measures to be undertaken, methods and formats of the meeting, contributions of the participants, presence of all relevant stakeholders, possibilities and levels of participation, context and timing of the meeting, objectives achieved in the meeting, if the meeting had changed their point of view with regard to the planning and overall assessment of the meeting, etc. Results showed that the outcome of the PPP was very encouraging, although it could be improved (CHS, 2016).

With regard to this work, stakeholders should mainly consider the over-exploitation of the Jumilla-Villena aquifer. In fact, this is one of 43 issues of the Schema of Important Issues that the Segura River Basin Authority has raised for the hydrological cycle from 2015 to 2021. Furthermore, the achievement of the 
good quantitative status, as establish by the WFD, has been derogated until 2027 for the Jumilla-Villena aquifer because of the over-exploitation. Then, a work as that here presented can help in the decisionmaking process of a PPP because the results of the methodology are easily understandable for all stakeholders including non-technicians or non-experts.

The environmental objectives were to revert current trends and restoring good ecological, qualitative and quantitative status, which will cause the piezometric levels not continue to decline. The environmental objectives must be balanced with the economic sustainability of the area.

Several measures have been undertaken by the Segura Water Agency to face these problems. The use of external water resources by means of the Júcar-Vinalopó transfer and desalination plants would allow, if necessary, the replacement of non-renewable groundwater resources. The connection to the infrastructure of Taibilla Canals Community (TCM) in the municipalities of Yecla and Jumilla, if carried out, would in the future allow the replacement of groundwater resources for urban use by other resources allocated to the TCM, which would reduce the extraction from the Segura water bodies. These actions should be performed in coordination with the Júcar River Water Authority because the Jumilla-Villena aquifer is shared with that river basin. In that case, Spain's National Water Plan will set the points of connections and water prices of the new external resources and to weigh up the cost of the construction of the new infrastructure required. In this sense, the Segura Water Agency performed simulations using different prices for the new external resources. An analysis of payment capacity of the users of the area through elasticity of demand curves were carried out. Other measures analyzed in the PPP were reordering water rights, reducing the water abstracted for irrigation purposes, that is used outside the limits of the aquifer, and more control of overexploitation and water storage. The reduction of irrigated areas by gradual acquisition of water rights will be selectively applied on crop areas with lower productivity. However, this would imply higher costs and greater loss of jobs which would lead to a reversal in the socio-economic development in the area. This situation would be translated into disproportionate costs and unaffordable socio-economic losses.

As a summary, the specific objectives to be reached for the Jumilla-Villena aquifer with the PPP are:

- Good quantitative status of the aquifer as established by the WFD: the actual annual aquifer water balance is negative (i.e., the total abstractions from the aquifer has exceed the natural recharge), thus leading to a continuous trend in the decrease of groundwater levels and possible problems in land subsidence. 
Furthermore, with this decreasing trend for the following decades it is reasonable to assume the possible future exhaustion of the aquifer. Therefore, the reverse of such situation should be undertaken.

- Good chemical status of the aquifer as established by the WFD: there is an upward trend in observed concentrations of hazardous substances. Accordingly to the WFD these are substances or groups of substances that are toxic, persistent and liable to bio-accumulate, and other substances or groups of substances which give rise to an equivalent level of concern. In these sense, higher concentrations of $\mathrm{SO}_{4}^{-2}, \mathrm{Cl}^{-}, \mathrm{Na}^{-}$and $\mathrm{Ca}^{2+}$ have been recorded. Moreover, the increase in nitrate concentrations, as a result of the fertilizer application in irrigated crops, and the water intrusion are becoming important issues in the region. Accordingly to EU water legislation, the limit in nitrate concentration in groundwater bodies is 50 $\mathrm{mg} / \mathrm{l}$.

- Recuperation of springs and wetlands: the intensive exploitations during the last decades have caused the disappearance of the springs Norica and Chopo, which had an average annual discharge of 0.6 and $6 \mathrm{hm}^{3}$, respectively.

- High irrigated area and crop profitability: agricultures are intended to obtain high net benefits.

- Short realization time between planning time and realization time.

- Low implementation costs of measures (maintenance, management and control of those measures).

- Increase regional productivity, sustainable tourism development and creation of employment: increasing the per capita income of the region.

- Improve recreational opportunities and the satisfaction of the recreational spaces.

This work is mainly focused on the achievement of the good quantitative status of the aquifer by means of the definition of future pumping well strategies. We have shown that either with the existing water abstractions or with those obtained for all simulated future scenarios, the recovery of the aquifer to the levels before any major abstractions cannot be achieved in the short run. In fact, the good status of the water body has been derogated until 2027. Furthermore, the achievement of the good quantitative status would also avoid other potential environmental damages such as quality pollution or land subsidence. Lower groundwater abstractions would lead to smaller irrigated crop areas and fertilizer applied, while avoiding land subsidence. It is worthwhile mentioning that with the current situation at the aquifer the nitrate concentrations are below standards and no significant land subsidence has been observed. 
The future scenarios simulated with regard to pumping strategies will lead to different environmental impacts (e.g., water supply-and-demand imbalance, disappearance of springs and wetlands, groundwater levels decline, land subsidence related to withdrawals of groundwater) and levels of socio-economic development of the region (e.g., higher benefits for agricultures on account of larger irrigated crop areas, water resources for sustainable development of tourism or industrial sector). They also would lead to a different degree of acceptance or satisfaction among stakeholders. For instance, in the public participation project the environmental organizations should be expected to support pumping scenarios S1 and S2, while agricultures or the tourism sector are expected to support scenarios S3 and S4. Therefore, these results could help in defining the best groundwater management practices for the aquifer.

Subsequently, as a summary we present the alternative actions to be considered by the stakeholders once we have set out the current environmental and socio-economic situation of the aquifer, the aquifer management during the last decades, the stakeholders involved in the decision-making process, the objectives expected to be achieved and the future scenarios regarding the water abstracted:

- Control/Restriction of groundwater use: reduction of irrigated agricultural area; land-use changes for adaptation to exploitation plans (e.g., establishment of protected areas, change of crops or dry farming; reduction of water allotment in drought periods (e.g., in summer); improvement in extraction controls and in irrigation efficiency; and control of water resources by application of satellite remote sensing. However, a thorough control may lead to a strong opposition among water users, and to negative political consequences.

- Rational and efficient conjunctive use of groundwater and surface water: groundwater substitution by using resources from interbasin transfers and desalination and sewage water plants; use of surface water for agricultural, industrial or urban water supply; and implementation of water banking.

- Water demand and fertilizer reduction by economic instruments: implementation of fertilizer standards, water and fertilizer taxes; and water trading (which is the process of buying and selling of water access entitlements, also often called water rights).

\section{Conclusions}

This work can help in the decision-making process of a public participation project and stakeholders' engagement in the water resources management of the Jumilla-Villena aquifer (Spain). We have set out 
how the current environmental and socio-economic situation of the region relies on the use of groundwater, and we have presented the management practices for the aquifer during the last decades. The decisions adopted regarding pumping strategies during that period led the aquifer to be officially declared as overexploited. This entails negative consequences in terms of the quantity and quality of the available resources as established by the European Water Framework Directive (WFD). By making use of a calibrated groundwater flow model, which takes into account the physical behavior of the groundwater system, we have simulated future pumping well strategies. Furthermore, we have simulated one of this future pumping scenario (the most water demanding) using a MonteCarlo approach, thus being able to carry out an uncertainty assessment on groundwater levels. This has been performed using an ensemble of calibrated $K$ fields, which present a wide range of groundwater levels because of the $K$ uncertainty. It should be noted, that a higher uncertainty in the results would have been obtained without the use of an inverse method (i.e., without calibrating the $K$ fields), thus showing the worth of using such techniques. The simulated pumping scenarios lead to different environmental impacts and levels of socio-economic development of the region, and hence, to a different degree of acceptance or satisfaction among stakeholders. The stakeholders, either implied in the decision making process or affected by the measures adopted at the groundwater system, have been identified. The objectives pursued with the public participation and the stakeholders' involvement have also been raised. They range from reaching a good quantitative and chemical status at the aquifer, recuperation of springs and wetlands, high irrigated area and crop profitability, short realization time between planning time and realization time, low implementation costs of measures to increase regional productivity, sustainable tourism development and creation of employment. Between these objectives we have focused on the achievement of the good quantitative status of the aquifer by means of the definition of the future pumping well strategies. We have shown that either with the existing water abstractions or with those obtained for all simulated future scenarios the recovery of the aquifer to the levels before any major abstractions cannot be achieved in the short run. Additionally, the achievement of the good quantitative status would also avoid other potential environmental damages such as quality pollution or land subsidence.

The alternative actions to be considered by the stakeholders are also provided, which cover control or restriction of groundwater use, rational and efficient conjunctive use of groundwater and surface water, and water demand and fertilizer reduction by means of economic instruments. 
Finally, with all that information a public participation project and stakeholders' engagement in the water resources management of the Jumilla-Villena aquifer (Spain) could be carried out in a more successful way, since results are easily understandable even for non-technicians and non-experts. This research can be used as a decision support system to define the best management policies for the groundwater system. It aims to contribute to the ongoing policy process in the European Union (Water Framework and Groundwater Directives), which requires the public participation to enhance the water resources management at water bodies.

\section{References}

Arhonditsis, G.B., Perhar, G., Zhang, W., Massos, E., Shi, M., Das, A. (2008). Addressing equifinality and uncertainty in eutrophication models, Water Resources Research, 44, W01420, doi:10.1029/2007WR005862.

Bacchus, S.T. (2000). Uncalculated impacts of unsustainable aquifer yield including evidence of subsurface interbasin flow. Journal of the American Water Resources Association, 36(3), 457-481.

Capilla, J. E., Llopis-Albert, C. (2009). Gradual Conditioning of Non-Gaussian Transmissivity Fields to Flow and Mass Transport Data. Journal of Hydrology, 371, 66-74. doi: 10.1016/j.jhydrol.2009.03.015.

CHJ (Júcar Water Agency) (2016). Júcar river basin authority. http://www.chj.es/

CHS (Segura Water Agency) (2016). Segura river basin authority. http://www.chsegura.es/

Custodio, E. (2002). Aquifer overexploitation: what does it mean? Hydrogeology Journal, 10, 254-277.

Delgado, J.A. \& Shaffer, M.J. (2008). Nitrogen management modeling techniques: assessing cropping systems/landscape combinations. In: Hatfield, J.L., Follet, R.F. (Eds). Nitrogen in the environment: sources, problems, and management. Elsevier Science, Netherlands, 539-570.

EC (2000). Directive 2000/60/EC of the European Parliament and of the Council of October 232000 Establishing a Framework for Community Action in the Field of Water Policy. Official Journal of the European Communities, L327/1eL327/72. 22.12.2000.

EC (2006). Directive 2006/118/EC of the European Parliament and of the Council of 12 December 2006 on the protection of groundwater against pollution and deterioration. 
Gómez-Hernández, J.J., Srivastava, R.M. (1990). ISIM3D: An ANSI-C three dimensional multiple indicator conditional simulation program. Computer and Geosciences 16 (4), 395-440.

Harbaugh, A.W., Banta, E.R., Hill, M.C. and McDonald, M.G. (2000). MODFLOW- 2000, The U.S. Geological Survey modular groundwater model-User guide to modularization concepts and the groundwater flow process. US Geol. Surv. Open-File Rep 00-92, 12.

Hu, L.Y. (2000). Gradual deformation and iterative calibration of Gaussian related stochastic models. Mathematical Geology, 32 (1), 87-108.

Jagelke, J. and Barthel, R. (2005). Conceptualization and implementation of a regional groundwater model for the Neckar catchment in the framework of an integrated regional model. Advances in Geosciences, 5, $105-111$.

Llopis-Albert, C. (2008). Stochastic inverse modeling conditional to flow, mass transport and secondary information. Edited by Universitat Politècnica de València (Spain). ISBN: 978-84-691-9796-7.

Llopis-Albert, C. and Capilla, J.E. (2009). Gradual Conditioning of Non-Gaussian Transmissivity Fields to Flow and Mass Transport Data. Demonstration on a Synthetic Aquifer. Journal of Hydrology, 371, 53-55. doi: 10.1016/j.jhydrol.2009.03.014.

Llopis-Albert, C. and Capilla, J.E., (2009a). Gradual Conditioning of Non-Gaussian Transmissivity Fields to Flow and Mass Transport Data. Application to the Macrodispersion Experiment (MADE-2) site, on Columbus Air Force Base in Mississippi (USA). Journal of Hydrology, 371, 75-84. doi: 10.1016/j.jhydrol.2009.03.016.

Llopis-Albert, C. and Capilla, J.E., 2010. Stochastic simulation of non-Gaussian 3D conductivity fields in a fractured medium with multiple statistical populations: a case study. Journal of Hydrologic Engineering, 15(7), 554-566. doi: 10.1061/(ASCE)HE.1943-5584.0000214.

Llopis-Albert, C. and Capilla, J.E. (2010a). Stochastic inverse modeling of hydraulic conductivity fields taking into account independent stochastic structures: A 3D case study. Journal of Hydrology, 391, 277288. doi: 10.1016/j.jhydrol.2010.07.028.

Llopis-Albert, C., Palacios-Marqués, D., Merigó, J.M. (2014). A coupled stochastic inverse-management framework for dealing with nonpoint agriculture pollution under groundwater parameter uncertainty. Journal of Hydrology 511, 10-16. doi: 10.1016/j.jhydrol.2014.01.021. 
Llopis-Albert, C., Pulido-Velazquez, D. (2014). Discussion about the validity of sharp-interface models to deal with seawater intrusion in coastal aquifers. Hydrological Processes 28(10), 3642-3654.

Llopis-Albert, C., Pulido-Velazquez, D. (2015). Using MODFLOW code to approach transient hydraulic head with a sharp-interface solution. Hydrological Processes 29(8), 2052-2064. doi: 10.1002/hyp.10354.

Llopis-Albert, C., Merigó, J.M, Palacios-Marqués, D. (2015). Structure Adaptation in Stochastic Inverse Methods for Integrating Information. Water Resources Management 29(1), 95-107. doi:10.1007/s11269014-0829-2.

Llopis-Albert, C., Merigó, J.M., Xu, Y. (2016). A coupled stochastic inverse/sharp interface seawater intrusion approach for coastal aquifers under groundwater parameter uncertainty. Journal of Hydrology 540, 774-783. doi:10.1016/j.jhydrol.2016.06.065.

MAGRAMA (2013). Program AGUA. Ministry of Agriculture, Food and Environment, Spain.

McDonald, M. G., \& Harbaugh, A. W. (1988). A modular three-dimensional finite-difference groundwater flow model. US Geological Survey Technical Manual of Water Resources Investigation, Book 6, US Geological Survey, Reston, Virginia, 586.

Molina, J.L., Pulido-Velazquez, M., Llopis-Albert, C., Peña-Haro, S. (2013). Stochastic hydro-economic model for groundwater quality management using Bayesian networks. Water Science \& Technology 67(3), 579-586. doi: 10.2166/wst.2012.598.

Peña-Haro, S., Llopis-Albert, C., Pulido-Velazquez, M. (2010) Fertilizer standards for controlling groundwater nitrate pollution from agriculture: El Salobral-Los Llanos case study, Spain. Journal of Hydrology 392, 174-187. doi: 10.1016/j.jhydrol.2010.08.006.

Peña-Haro, S., Pulido-Velazquez, M., Llopis-Albert, C. (2011). Stochastic hydro-economic modeling for optimal management of agricultural groundwater nitrate pollution under hydraulic conductivity uncertainty. Environmental Modelling \& Software 26 (8), 999-1008. doi: 10.1016/j.envsoft.2011.02.010.

Pulido-Velazquez, D.; Llopis-Albert, C.; Peña-Haro, S.; Pulido-Velazquez, M. (2011). Efficient conceptual model for simulating the effect of aquifer heterogeneity on natural groundwater discharge to rivers. Advances in Water Resources, 34(11), 1377-1389. doi:10.1016/j.advwatres.2011.07.010.

Reichert, P., Borsuk, M., Hostmann, M., Schweizer, S., Spörri, C., Tockner, K. and Truffer, B. (2005). Concepts of decision support for river rehabilitation. Environmental. Modeling \& Software, 22, 188-201. 
Tilman D., Fargione J., Wolff B., D’Antonio C., Dobson A. Howarth R. (2001). Forecasting agriculturally driven global environmental change. Science, 292, 281-284.

Wright, S.A.L., Fritsch, O. (2011). Operationalising active involvement in the EU Water Framework Directive: Why, when and how? Ecological Economics, 70(12), 2268-2274.

Zhou, H., Gómez-Hernández, J.J., Li, L. (2014). Inverse methods in hydrogeology: Evolution and recent trends. Advances in Water Resources 63, 22-37. Doi: 10.1016/j.advwatres.2013.10.014. 


\section{TABLES}

Table 1. Water demand and uses for the groundwater abstractions.

\begin{tabular}{|c|c|c|c|c|c|c|c|c|c|c|c|c|}
\hline \multicolumn{3}{|c|}{$\begin{array}{l}\text { Agricultural water } \\
\text { demand ( } \mathrm{Mm}^{3} / \text { year) }\end{array}$} & \multicolumn{3}{|c|}{$\begin{array}{l}\text { Abstractions for } \\
\text { irrigation }\left(\mathrm{Mm}^{3} / \text { year) }\right.\end{array}$} & \multicolumn{3}{|c|}{$\begin{array}{l}\text { Abstractions for } \\
\text { domestic water } \\
\text { ( } \mathrm{Mm}^{3} / \text { year) }\end{array}$} & \multirow{2}{*}{$\begin{array}{c}\text { Other uses } \\
\left(\mathrm{Mm}^{3} / \text { year) }\right.\end{array}$} & \multicolumn{3}{|c|}{ Total uses (Mm³/year) } \\
\hline $\begin{array}{c}\text { Segura } \\
\text { Basin }\end{array}$ & $\begin{array}{l}\text { Júcar } \\
\text { Basin }\end{array}$ & Total & $\begin{array}{l}\text { Segura } \\
\text { Basin }\end{array}$ & $\begin{array}{l}\text { Júcar } \\
\text { Basin }\end{array}$ & Total & $\begin{array}{c}\text { Segura } \\
\text { Basin }\end{array}$ & $\begin{array}{l}\text { Júcar } \\
\text { Basin }\end{array}$ & Total & & $\begin{array}{l}\text { Segura } \\
\text { Basin }\end{array}$ & $\begin{array}{l}\text { Júcar } \\
\text { Basin }\end{array}$ & Total \\
\hline 28 & 17 & 45 & 21 & 17 & 38 & 1 & 6 & 7 & 0.7 & 22 & 24 & 46 \\
\hline
\end{tabular}

Table 2. Annual water balance of the aquifer.

\begin{tabular}{|c|c|c|c|c|}
\hline $\begin{array}{l}\text { Recharge } \\
\left(\mathrm{Mm}^{3} / \text { year }\right)\end{array}$ & $\begin{array}{l}\text { Actual pumping } \\
\left(\mathrm{Mm}^{3} / \text { year }\right)\end{array}$ & $\begin{array}{l}\text { Storage variation } \\
\left(\mathrm{Mm}^{3} / \text { year }\right)\end{array}$ & $\begin{array}{l}\text { Total drawdown since } \\
\text { natural regime }(\mathrm{m})\end{array}$ & $\begin{array}{l}\text { Water table depletion rate during the last } \\
10 \text { years }(\mathrm{m} / \text { year })\end{array}$ \\
\hline 7.5 & 42.7 & -35 & 115 & 3.5 \\
\hline
\end{tabular}

\section{FIGURE \& CAPTIONS}

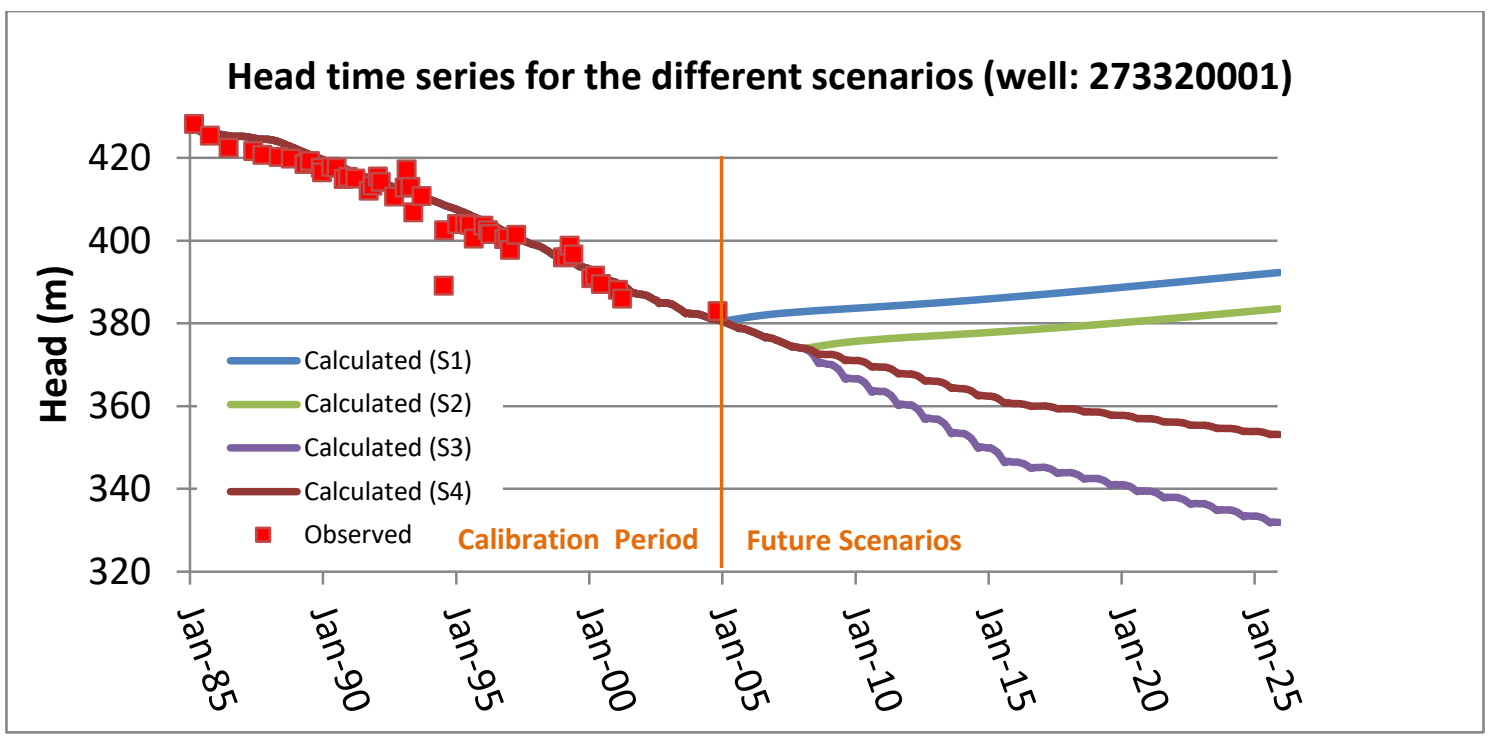

Figure 1. Head time series for the different scenarios for one of the calibrated K fields at a specific well. 


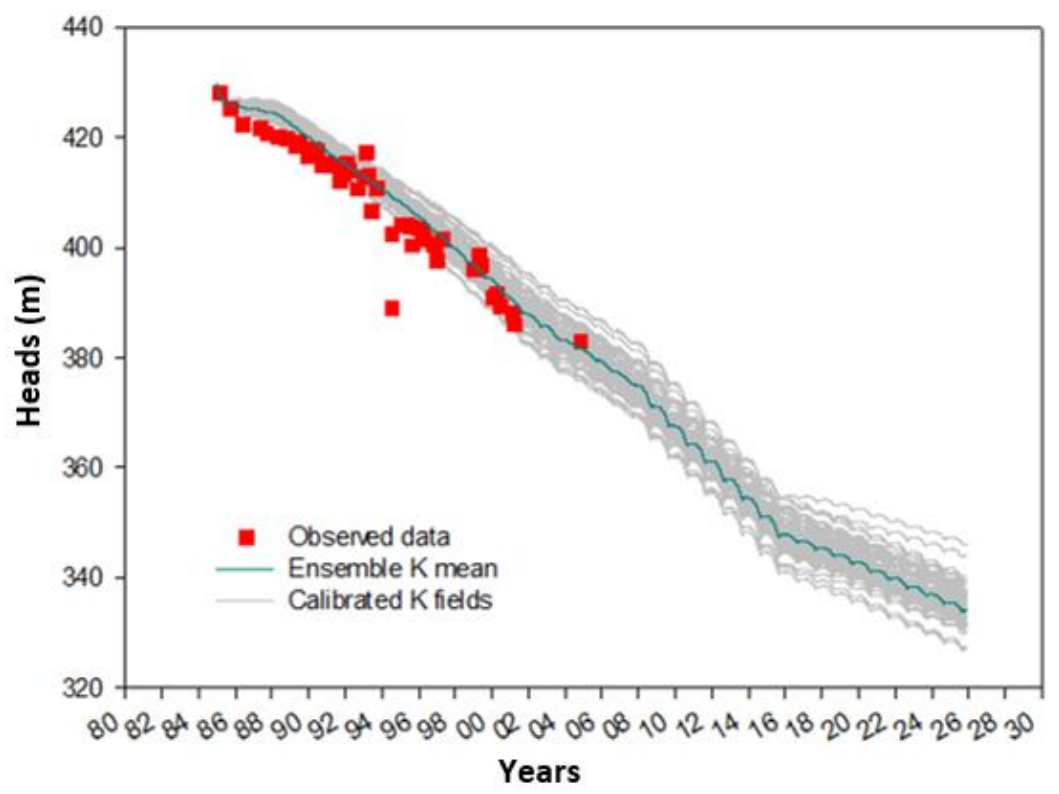

Figure 2. Head time series for the ensemble calibrated K fields and Scenario S3 at a specific well 